\title{
A NOVEL OF BEZAFIBRATE ANALYSIS METHODS IN URINE (IN VITRO) USING SOLID PHASE EXTRACTION- HIGH-PERFORMANCE LIQUID CHROMATOGRAPHY-UV DETECTOR
}

\author{
IYAN SOPYAN ${ }^{*}$, WIDIASTUTY IRAWATI ${ }^{2}$, WIWIEK INDRIYATI ${ }^{2}$
}

\begin{abstract}
1Depertemen of Pharmaceutics and Technology of Pharmacy, Faculty of Pharmacy, Universitas Padjadjaran, ${ }^{2}$ Depertemen of Pharmaceutical analysis and Medicinal Chemistry, Faculty of Pharmacy, Universitas Padjadjaran Email: sopyan1os@gmail.com
\end{abstract}

Received: 25 Sep 2017, Revised and Accepted: 28 Nov 2017

\begin{abstract}
Objective: Bezafibrate is the second generation of fibrate groups used as the drug of choice in the treatment of hyperlipidemia. The purpose of this study is to obtained a validated method for analyzing bezafibrate in urine using solid phase extraction (SPE)-High performance liquid chromatography (HPLC).
\end{abstract}

Methods: Solid phase extraction (SPE) using hydrophilic-lipophilic balance (HLB) cartridge was performed for bezafibrate extraction from urine, afterward, a validation of analysis method using high-performance liquid chromatography (HPLC)-(UV) detection was conducted to parameters, including: selectivity (Rs), linearity (r), accuracy, precision, limit of detection (LOD) and limit of quantification (LOQ).

Results: Recovery extraction using SPE resulted \%recovery $85-110 \%$. The analysis was performed by high-performance liquid chromatography using reversed phase, C18 octadecylsilane (ODS) columns $250 \times 26 \mathrm{~mm}$, particle size $10 \mu \mathrm{l}$, with the composition of $0.01 \mathrm{M}$ acetate buffer with pH 3.55: with percent composition (45:55) and $0.8 \mathrm{ml} /$ minute on $230 \mathrm{~nm}$ UV detection. Validation includes selectivity, linearity, accuracy, precision LOD, and LOQ have fulfilled requirement value.

Conclusion: The result of recovery extraction using SPE and validation of method exhibited the values that fulfilled the requirements and can be used for analysis bezafibrate in the urine.

Keywords: Bezafibrate, HPLC, SPE, Urine

(C) 2018 The Authors. Published by Innovare Academic Sciences Pvt Ltd. This is an open-access article under the CC BY license (http://creativecommons.org/licenses/by/4.0/) DOI: http://dx.doi.org/10.22159/ijap.2018v10i1.22769

\section{INTRODUCTION}

Hyperlipidemia is a global problem that is facing today, this is due to changes in lifestyle that occurs [1]. Bezafibrate (2-[4-2-[4chlorobenzamido]-ethyl phenoxy]-2methylpropanoic acid) is a derivative of a known fibrate compound as a class of lipid-lowering drugs that is often prescribed [2]. The mechanism of decreasing lipid levels by bezafibrate is by increasing the release of triglycerides, cholesterol, low-density lipoprotein and raising the amount of high-density lipoprotein, bezafibrate works as a peroxisome proliferation activated receptor agonist (PPARs) [3]. Bezafibrate is expressed about $95 \%$ by urine in the form of unchanged bezafibrate [4].

Drugs or metabolite analysis in urine or plasma commonly used HPLCUV method to reach good result [5, 6]. Studies that have been performed for bezafibrate analysis include: bezafibrate in plasma and urine using HPLC, where plasma bezafibrate is extracted with diethyl ether first, while bezafibrate in urine is directly analyzed after being diluted by mobile phase, its time consuming and resulted low accuracy [7] bezafibrate in human plasma applied in tablet dispersion system by HPLC method $[8,9]$ bezafibrate in pharmaceutical preparations by polarography method [8] bezafibrate in rat serum with Ag-Nitrate using HPLC method [10] but, the procedure of drug or metabolite isolation is complicated; bezafibrate in a pharmaceutical formulation of the HPLC method [1] especially just for high doses. Until now has not been reported an analysis of bezafibrate in biological fluids with SPE by UV detector. HPLC is a good method for analysis in biological fluids because it has good selectivity and sensitivity values and SPE is a method that excellent in the extraction of compounds with small levels and in a complex matrix [11,12]. In this work, we attempt to get the simple, rapid and accurate of bezafibrate analysis method in human urine using SPE-HPLC-UV detector.

\section{MATERIALS AND METHODS}

\section{Materials}

Bezafibrate (Bezalip Purity $>98 \%$ purchased from PT Rajawali Nusindo), acetonitrile HPLC grade (JT Baker), methanol pro analysis
(Merck), sodium acetate (Bratachem), acetic acid glacial (Bratachem), aquabidestillata (IKA).

\section{Equipment}

A set of HPLC (Shimadzu LC-10 ATVP) equipped with SPD UV-Vis detector) ODS column (Phenomenex) (length of $250 \mathrm{~nm}, 4.6 \mathrm{~mm}$ inner diameter, $10 \mu \mathrm{m}$ particle size), UV-Vis spectrophotometer (Analytical Jena, Specord 200), SPE cartridge HLB $30 \mathrm{mg} 1 \mathrm{cc}$ (Oasis). pH meter (Ohmeter), ultrasonic bath (NEY 1510).

\section{Methods}

\section{Preparation of working standard of bezafibrate}

Accurately weigh of $2 \mathrm{~g}$ of bezafibrate were dissolved in methanol add to $100 \mathrm{ml}$, obtained standard solution with a concentration of about $20.000 \mu \mathrm{g} / \mathrm{ml}$ which was subsequently diluted to $200 \mu \mathrm{g} / \mathrm{ml}$.

Determination of molar extinction

Prepare a series of bezafibrate solutions from the stock solution with concentrations of 11,22 , and $33 \mu \mathrm{M}$. The three solutions were then measured their maximum wavelength with the speculator and read the absorption of each concentration at the maximum bezafibrate wavelength and determined the value of its molar extension.

\section{Preparation of mobile phase}

Prepared of 0.1 molar acetate buffer with $\mathrm{pH} 3.5$ by dissolving 0.234 $\mathrm{g}$ of sodium acetate up to $300 \mathrm{ml}$. The solution is stirred using a magnetic stirrer. The $\mathrm{pH}$ adjustment was performed with the addition of glacial acetic acid. Buffer solution then filtered using a filter membrane of $0.45 \mu \mathrm{l}$, and degassing. A number of acetonitrile to be used as a mobile phase are degassed before use.

Optimization HPLC analysis condition

To obtain optimum condition, an experiment with various concentration of mobile phase of HPLC system to be used is column 
ODS/C18 (octadecylsilane), length $250 \mathrm{~mm}$, inner diameter $4.6 \mathrm{~mm}$ and particle size $10 \mu \mathrm{m}$ phase of ammonium acetate $(0.01 \mathrm{M}, \mathrm{pH} 3.5$, regulated by addition of acetic acid): Acetonitrile with optional \% composition were (35:65, 40:60, and 45:55), flow rate will be set in 0.8; 0.9; or $1 \mathrm{ml} / \mathrm{min}$ at UV Detection 230. The optimum condition is stated by reaching a peak resolution (Rs) greater than 1.5 and produce fastest in analysis time.

\section{Optimization of extraction using SPE}

The extraction was done by addition method of bezafibrate in urine with a variation of concentration 2,$4 ; 3.8 ; 4.8 ; 6.2$; and $7.4 \mu \mathrm{g} / \mathrm{ml}$ then extracted with SPE using HLB cartridge. The optimal conditions of extraction are expressed when the recovery value of extraction is in the range $85-100 \%$

\section{Validation of analysis method}

Some aspects measured in the validation method are selectivity, linearity, precision, accuracy, LOD and LOQ [12].

\section{Selectivity}

Selectivity determination is conducted by calculating the value of chromatogram resolution (Rs) from the chromatogram.

\section{Linearity}

While the linearity test obtained from the measurement data of standard series solution that has been made five variations of concentration $2.4 ; 3,4 ; 4.8 ; 6.2 ;$ and $7.8 \mu \mathrm{g} / \mathrm{ml}$ to obtain the calibration curve and correlation coefficient $\left(\mathrm{r}^{2}\right)$.

\section{LOD and LOQ}

Measurement of the limit of detection and limit of quantification were calculated statistically using linear regression of calibration curve [13].

\section{Precision}

The repeatability test is performed by injecting of 6 times bezafibrate concentration of $4.8 \mu \mathrm{g} / \mathrm{ml}$ in urine in the same day so that the data obtained will be expressed as the relative standard deviation (\% RSD) [13].

\section{Accuracy}

The accuracy test was performed by preparing a standard solution with 3 and $7 \mu \mathrm{g} / \mathrm{ml}$ of bezafibrate using blank urine, then it was analyzed using SPE, both of solution was injected 3 times into the HPLC tool in optimum condition. The accuracy value is expressed as (\%) recovery [13].

\section{RESULTS AND DISCUSSION}

\section{Determination of molar extinction}

The determination of molar extension $(\varepsilon)$ results bezafibrate was carried out on three concentrations of 11,22 , and $33 \mu \mathrm{M}$ in methanol at a maximum bezafibrate wavelength of $230 \mathrm{~nm}$ (table 1).

Table 1: Results of determination of bezafibrate molar extinction in wavelength $230 \mathrm{~nm}(\varepsilon)$

\begin{tabular}{llll}
\hline No. & Concentration molar $(\mathbf{M})$ & Absorbance & Molar exctingtion $(\boldsymbol{\varepsilon})\left(\mathbf{M}^{-1} \mathbf{c m}^{-\mathbf{1}}\right)$ \\
\hline $\mathrm{n}=3$ & $11 \times 10^{-6}$ & 0.2272 & 20700 \\
& $22 \times 10^{-6}$ & 0.5013 & 22700 \\
& $33 \times 10^{-6}$ & 0.5750 & 23000 \\
$\bar{X}_{ \pm}$SD & & & $22133.33 \pm 1020.893$ \\
\hline
\end{tabular}

Values represent mean $\pm \mathrm{SD}, \mathrm{n}=3$.

The results of bezafibrate molar exctingtion value presented an average value of $22133.33 \mathrm{M}^{-1} \mathrm{~cm}^{-1}$. Its value indicates that bezafibrate is possible to be detected by UV detector in the HPLC system. The minimum value of molar exctingtion that can be detected in UV system must be greater than $10.000 \mathrm{M}^{-1} \mathrm{~cm}^{-1}$ [12].

\section{Optimization HPLC condition}

Optimization of HPLC conditions is carried out against the main chromatographic parameters of resolution, retention time, and flow rate of mobile phases of various compositions. The result of optimizing HPLC condition for bezafibrate is as follows: Column: LiChroCART C18, particle size $10 \mu \mathrm{m}$, column length $250 \mathrm{~mm}$. mobile phase: Ammonium Acetate (0.01 M, with pH 3.5): acetonitrile with
\% composition (55:45), at UV detection $254 \mathrm{~nm}$, flow rate: 0.8 $\mathrm{ml} / \mathrm{min}$ and injection volume: $10 \mu \mathrm{l}$. The Rs value obtained in this condition is 1.55 and retention time of bezafibrate is $6 \mathrm{~min}$. Base on its result, analysis condition of HPLC was stated as an optimal condition. The short retention times ( 6 minutes) help to improve the efficiency of the analysis so that it is more effective than previous studies $[8,12]$.

\section{Recovery of extraction}

The result of the extraction result of bezafibrate test (table 2) was done with concentration of $2.4 \mu \mathrm{g} / \mathrm{ml}, 4.8 \mu \mathrm{g} / \mathrm{ml}$, and $7.4 \mu \mathrm{g} / \mathrm{ml}$. The variation of the concentration was based on the level of bezafibrate secreted into urine ie about $4.8 \mu \mathrm{g} / \mathrm{ml}$ as previously study [8].

Table 2: Result of recovery extraction

\begin{tabular}{llll}
\hline Replication & Concentration bezafibrate $\mathbf{2 . 4} \boldsymbol{\mu g} / \mathbf{m l}$ & Concentration bezafibrate $\mathbf{4 . 8} \boldsymbol{\mu g} / \mathbf{m l}$ & Concentration bezafibrate $\mathbf{7 . 4} \boldsymbol{\mu g} / \mathbf{m l}$ \\
\hline $\mathrm{n}=3$ & 88.4408 & 94.9437 & 96.2171 \\
& 89.0622 & 94.9184 & 96.4800 \\
& 90.7384 & 94.9888 & 98.2556 \\
$\overline{\mathrm{X}} \pm \mathrm{SD}$ & $89.4138 \pm 1.19$ & $92.9503 \pm 0.03$ & $97.3179 \pm 1.11$ \\
\hline
\end{tabular}

Values represent mean $\pm \mathrm{SD}, \mathrm{n}=3$.

The result of recovery extraction for the concentration of bezafibrate $2.4 \mu \mathrm{g} / \mathrm{ml}$ was valued $88.24 \%$, bezafibrate with $4.8 \mu \mathrm{g} / \mathrm{ml}$ was $92.55 \%$, and bezafibrate with $7.8 \mu \mathrm{g} / \mathrm{ml}$ equal to $97.01 \%$ respectively. Based on the results of the analysis, the \% recovery of the three bezafibrate sample concentrations is eligible because the value is in the range of $80-120 \%$ [7, 13-15]. SPE method is very effective to trace analysis in a biological fluid. It is the recovery of extraction can be reach up to $99 \%$. Its value higher than liquid-liquid extraction as previously studies that only reach $80-85 \%[3,7]$.

\section{Validation of analysis method}

Validation of the analysis method includes parameter selectivity, linearity, accuracy, precision, LOD, LOQ, and system suitability test.

\section{Selectivity}

The selectivity test is performed by calculating the resolution value of the peak of the sample chromatogram and the other peak of the separate chromatogram (not overlapping). 


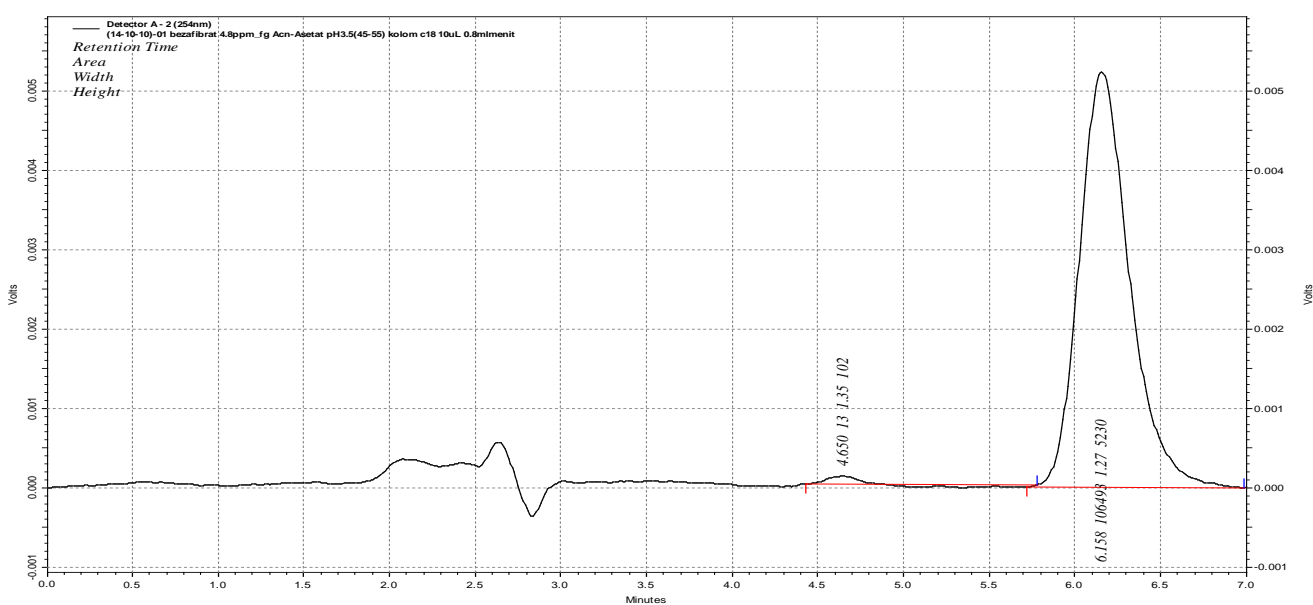

Fig. 1: Chromatogram for resolution of peak

The Rs value (fig. 1) obtained from the analysis is 1.55. Its represents the good separation peaks on chromatograms between bezafibrate and impurity metabolites (extracted body metabolites).

The standard of resolution value allowed is greater than 1.5 [12], this indicates that the resolution value has fulfilled the validation requirements. The chromatogram is relatively clean from impurity so as not to interfere with the process of bezafibrate quantification.

\section{Linearity}

The linearity test (fig. 2) is done to find out the response of the method of analysis to the variation of the sample concentration in the form of a straight-line calibration curve. The parameter used is the correlation coefficient $\left(\mathrm{r}^{2}\right)$ which will state the linear relationship of the calibration curve. The calibration curve was made by making 5 variations of bezafibrate concentrations in urine. Subsequently undergoing extraction step with SPE, at each concentration 3 repetitions were performed $(n=3)$. Then we create a linear equation. Based on the calculation of linear line equation, the correlation coefficient (r) is 0.997 with the straight-line equation $\mathrm{y}=$ $48019 \mathrm{x}-11141$. The $\mathrm{r}^{2}$ value meets the linearity requirement for the valid method of analysis that is $>0.995$ [12]. This result shows a curve of calibration can be used to quantify bezafibrate levels in the urine.

\section{LOD and LOQ determination}

The LOD and LOQ values were obtained from the calculation of bezafibrate calibration curve to the area of the chromatogram. The equation used is $\mathrm{y}=48019 \mathrm{x}-11141$ so that the LOD value to area ratio is $0.055 \mu \mathrm{g} / \mathrm{ml}$ and the LOQ to area ratio is $0.184 \mu \mathrm{g} / \mathrm{ml}$. Base on LOD and LOQ value, the method was sensitive enough to detect bezafibrate in urine [13]. SPE help the extraction efficiency that it will be assisted to increase detection of drug level in the analysis. SPE increases the efficiency of extraction so as to help improve drug level detection in the analysis $[11,16]$.

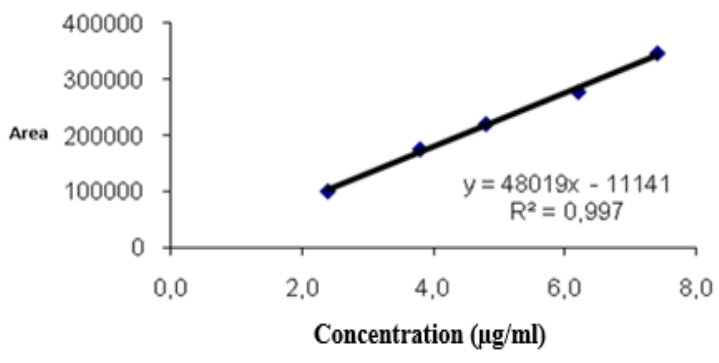

Fig. 2: Calibration curve of linearity

\section{Precision}

The precision test is done by measuring the bezafibrate sample of $4.8 \mu \mathrm{g} / \mathrm{ml}$ concentration using HPLC with repetition 6 times $(\mathrm{n}=6)$ was presented in table 3 . Based on the results of repeatability test, the \% RSD for the area of the chromatogram is $2.23 \%$. This indicates that the results of the repeatability test analysis were good enough and fulfilled the valid value, because a requirement RSD value for the biological fluid analysis must be less than $10 \%[13,17]$.

Table 3: Result of precision

\begin{tabular}{ll}
\hline Concentration of bezafibrate $(\boldsymbol{\mu g} / \mathbf{m l})$ & Peak area $(\mathbf{n = 6 )}$ \\
\hline 4.8 & 221332 \\
& 221273 \\
& 221437 \\
& 215477 \\
$\bar{X} \pm$ SD & 216546 \\
RSD $\%$ & 229424 \\
\hline
\end{tabular}

Values represent mean \pm SD, $n=6$.

\section{Accuracy}

Based on the results of the analysis, accuracy value fulfilled the validation criteria (fig. 4). Both of the concentration of bezafibrate with concentration $3 \mu \mathrm{g} / \mathrm{ml}$ and $7 \mu \mathrm{g} / \mathrm{ml}$ have $\%$ recovery $89.398 \%$ and $94.305 \%$ respectively. Percent recovery for accuracy allowed for a method of analysis in a biological matrix is $80-120 \%$ [13]. The method was accurate for bezafibrate quantification. 
Tabel 4: Result of accuracy

\begin{tabular}{|c|c|c|}
\hline \multirow[t]{2}{*}{ Replication } & \multicolumn{2}{|c|}{ Nominal concentration } \\
\hline & $3 \mu \mathrm{g} / \mathrm{ml}$ & $7 \mu \mathrm{g} / \mathrm{ml}$ \\
\hline \multirow[t]{3}{*}{ Peak area } & 112974 & 302940 \\
\hline & 119879 & 307326 \\
\hline & 120078 & 307182 \\
\hline Concentration base on calibration curve & 2.584 & 6.54 \\
\hline \multirow[t]{2}{*}{$(\mu \mathrm{g} / \mathrm{ml})$} & 2.728 & 6.63 \\
\hline & 2.326 & 6.62 \\
\hline $\bar{X}_{ \pm \mathrm{SD}}$ & $2.681 \pm 0.203676$ & $6.60 \pm 0.040$ \\
\hline RSD \% & 3.95 & 2.15 \\
\hline Recovery \% & $89.39 \pm 2.809561$ & $94.30 \pm 0.75$ \\
\hline $\bar{X}_{ \pm \mathrm{SD}}$ & & \\
\hline
\end{tabular}

Values represent mean $\pm \mathrm{SD}, \mathrm{n}=3$.

Table 5: System suitability

\begin{tabular}{ll}
\hline Parameters & RSD (\%) \\
\hline Retention time $(\mathrm{n}=6)$ & 1.09 \\
Peak area $(\mathrm{n}=6)$ & 2.23 \\
\hline
\end{tabular}

Values represent in RSD (relatif standar deviation), $n=6$.

\section{System suitability test}

The system suitability test (table 5). Is done to know that the system used can run effectively and parameter used is \% RSD. Its value must be fulfilled requirement that is $\mathrm{RSD}<10 \%$ for biological fluids [17]. Base on the value of \% RSD, the system was effective for running.

\section{CONCLUSION}

Extraction using SPE yields excellent results with percent recovery near $100 \%$ and it can be applied to bezafibrate analysis with a very small concentration in complicated matrices. The validation methods include parameters: selectivity, linearity, LOD, LOQ, accuracy, precision, and system suitability, proved that the method used has validity as required so it can be used to analyze bezafibrate human urine especially for routine analysis.

\section{ABBREVIATION}

SPE: solid phase extraction, HPLC: high-performance liquid chromatography, UV: ultraviolet, HLB: hydrophilic-lipophilic balance, LDL: low-density lipoprotein, LOD: limit of detection, LOQ: limit of quantification, SD; standard deviation, RSD: relative standard deviation, Rs: Resolution, ODS: octadecylsilane

\section{AUTHORS CONTRIBUTIONS}

All the authors have contributed equally.

\section{CONFLICT OF INTERESTS}

Declared none

\section{REFERENCES}

1. Silva MAB da, Melo LVL, Ribeiro RV, Souza JPM de, Lima JCS, Martins DT de 0 , et al. Levantamento etnobotânico de plantas utilizadas como anti-hiperlipidêmicas e anorexigenas pela populacao de Nova Xavantina-MT, Brasil. Rev Bras Pharmacogn 2010;20:549-62.

2. Vázquez M, Alegret M, Lopez M, Rodriguez C, Adzet T, Merlos M, et al. Different effects of fibrates on the microsomal fatty acid chain elongation and the acyl composition of phospholipids in guinea-pigs. Br J Pharmacol 1995;116:3337-43.

3. Borges NC do C, Mendes GD, Barrientos-Astigarraga RE, Zappi E, Mendes FD, De Nucci G. Comparative bioavailability study with two gemfibrozil tablet formulations in healthy volunteers. Arzneimittel-Forschung 2005;55:382-6.
4. Miller DB, Spence JD. Clinical pharmacokinetics of fibric acid derivatives (Fibrates). Clin Pharmacokinet 1998;34:155-62.

5. Zidan D, Ismaiel OA, Hassan WS, Shalaby A. Rapid and validated HPLC-UV method for determination of gemiloxacin in human urine. Int J Pharm Pharm Sci 2015; 7:104-8.

6. Jain HK, Deore DD. Bioanalytical method development and validation for estimation of clopidogrel bisulfate in human plasma by RP-HPLC. Int J Appl Pharm 2016;8:18-21.

7. Castoldi D, Monzani V, Tofanetti O. Determination of bezafibrate in human plasma and urine by high-performance liquid chromatography. J Chrom B: Biomed Sci Appl 1985;344:259-65.

8. Zhang W, Xiang B, Zhan Y, Yu L, Wang T, Wang C. HPLC method for the determination of bezafibrate in human plasma and application to a pharmacokinetic study of the bezafibrate dispersible tablet. J Chromatogr Sci 2008;46:844-7.

9. Blanchet B, Billemont B, Cramard J, Benichou AS, Chhun S, Harcouet L, et al. Validation of an HPLC-UV method for sorafenib determination in human plasma and application to cancer patients in routine clinical practice. J Pharm Biomed Anal 2009;49:1109-14.

10. Abdel Razak O, Belal SF, Bedair MM, Barakat NS, Haggag RS. Spectrophotometric and polarographic determination of enalapril and lisinopril using 2,4-dinitrofluorobenzene. J Pharm Biomed Anal 2003;31:701-11.

11. Muchtaridi M, Yuliani E, Sopyan I. Application off-line SPEHPLC/UV methods in the analysis in human (in vitro). Int J Pharm Pharm Sci 2015;8:255-61.

12. Anchisi C, Fadda AM, Maccioni AM, Dessì S. Determination of bezafibrate concentration by high-performance liquidchromatography in the serum of rats treated with lead nitrate. Il Farmaco 1998;53:690-2.

13. Snyder LR, JJ Kirkland, JL Glajch. Practical HPLC method development. 2nd Edition. New York: John Willey and Sons, Inc; 1997. p. 119-44, 643-728, 736.

14. Abshagen U, Bablok W, Koch K, Lang PD, Schmidt HaE, Senn M, et al. Disposition pharmacokinetics of bezafibrate in man. Eur J Clin Pharmacol 1979;16:31-8.

15. Huang Z, Pan XD, Huang B, Xu JJ, Wang ML, Ren YP. Determination of $15 \beta$-lactam antibiotics in pork muscle by matrix solid-phase dispersion extraction (MSPD) and ultrahigh pressure liquid chromatography-tandem mass spectrometry. Food Control 2016;66:145-50.

16. Sopyan I, Chandra W, Indriyati W, Sriwidodo. A new approach of ofloxacin analysis method in human blood plasma using solid-phase extraction-high performance liquid chromatography-ultraviolet. J Pharm Res 2017;11:996-1002.

17. Harmita APT. Analisis Fisikokimia. Depok: FMIPA UI; 2006. 